\title{
Histopathological study on basal cell carcinoma and squamous cell carcinoma of the skin
}

Mpu Kanoko', Achmad Tjarta', Masato Ueda ${ }^{2}$, Mochtar Hamzah $^{3}$, Herman Cipto ${ }^{3}$, Evert Poetiray ${ }^{4}$, Arman Mukhtar ${ }^{4}$, Santoso Cornain', Joedo Prihartono ${ }^{5}$, Setyawati Budiningsih', Yoshiyuki Ohno ${ }^{6}$, Nobuo iMunakata ${ }^{7}$, Masamitsu Ichihashi ${ }^{2}$

\begin{abstract}
Abstrak
Penelitian kanker kulit Indonesia - Jepang dilaksanakan untuk menelaah faktor risiko dan karakteristik gambaran klinikopatologi pada orarg Indonesia dan Jepang. Pada penelitian ini, dilakukan analisa gambaran histopatologik tumor ganas kulit non-melanoma yaitu karsinoma sel basal (KSB) dan karsinoma sel skuamosa (KSS) pada penderita di Indonesia. Menyadari bahwa radiasi sinar ultraviolet (UV) memegang peranan pada terjadinya kanker kulit non-melonoma, dicari hubungan antara gambaran histopatologik dengan lokasi tumor, yang berhubungan dengan daerah yang terpajan sinar matahari. Pada umumnya, ukurai tumor penderita di Indonesia lebih besar dari pada di Jepang. Karena itu dalam penelitian ini ditinjau pula hubungan antara besar tumor dengan gambaran histopatologik. Selama tahun 1996 sampai 1998 dikumpulkan 40 kasus karsinoma sel basal dan 16 kasus karsinoma sel skuamosa. Berdasarkan diferensiasi sel, dari 40 kasus karsinoma sel basal, 28 kasus dari jenis solid, 5 kasus jenis adenoid, 2 kasus jenis keratotik dan 5 kasus jenis campuran (solid-adenoid atau keratotik-adenoid). Dari 16 kasus karsinoma sel skuamosa, 12 kasus merupakan derajat I (berdiferensiasi baik) dan sisanya 4 kasus dengan derajat II (berdiferensiasi sedang). Karena dari 40 kasus, 39 diantaranya terdapat pada daerah yang ierpajan matahari, maka perbandingan antara jenis histopatologik dengan perbedaan lokasi tumor berdasarkan pajanan sinar matahari tidak dapat dinilai. Dari 16 kastss karsinoma sel skuamosa, 9 kasus terdapat pada daerah yang terpajan sinar matahari, 7 kasus lainnya pada daerah yang terlindung dari sinar matahari. Tidak terdapat perbedaan yang nyata yang dapat dibuktikan dengan jumlah kasus yang terbatas ini. Berdasarkan ukuran tumor dari 40 kasus karsinoma sel basal, 9 kasus berdiameter $1 \mathrm{~cm}$ atau kurang (KSB kecil) dan 31 kasus berdiameter lebih dari $1 \mathrm{~cm}$ (KSB besar). 13 kasus diantara KSB besar ini menunjukkan tipe pertumbuhan infiltratif dengan seklerosis. Agaknya karsinoma sel basal dengan ukuran besar sering berhubungan dengan sifat pertumbuhan infiltratif dengan seklerosis. Liantara 16 kasus karsinoma sel skuamosa, 7 kasus berdiameter $l \mathrm{~cm}$ atau kurang (KSS kecil) dan 9 lainnya berdiameter lebih dari $1 \mathrm{~cm}$ (KSS besar). Ke dua jenis ini tidak menunjukkan perbedaan tingkat diferensiasi sel yang jelas. Pengaruh sinar ultraviolet pada perubahan patologik kainker kulit non-melanoma akan diteliti lebih lanjut dengan menggunakan jumlah kasus yang lebih banyak.
\end{abstract}

\begin{abstract}
Department of Anatomic Pathology, Faculty of Medic
University of Indonesia, Jakarta 10430, Indonesia

Department of Dermatology, Kobe University School of Medicine, Kobe 650-0017, Japan

4 Department of Surgery, Faculty of Medicine, University of Indonesia, Jakarta 10430, Indonesia

5 Department of Community Medicine, Facuity of Medicine, University of Indonesia, Jakarta 10320, Indonesia

' Department of Preventive Medicine, Nagoya University School of Medicine, Nagoya 466-8550, Japan

7 Radiobiology Division, National Cancer Center Research Institute, Tokyo 104-0045, Japan
\end{abstract}

A collaborative study on skin cancer has been conducted to analyze the risk factors and clinico-pathological characteristics of skin cancers among both the Indonesian and the Japanese. In this study, we have analyzed the histopathological features of non-melanoma skin cancer (NMSC), basal cell carrinoma $(B C C)$ and squamous cell carcinoma (SCC) of Indonesian patients. Considering the fact that ultraviolet light (UV) radiation is the major cause of NMSC, we focus on studying the relationship between the histopathological finding and the location of the tumors, whether they were developed on sun-exposed sites or sun-protected sites. In addition, because it has been revealed that the size of NMSC in Indonesian was larger than those in Japanese, we also attempted to find the relationship between the tumor size of NMSC and the pathological characteristics. From period of 1996 to 1998, we could analyze the histopathological features in 40 cases of BCC and 16 cases of SCC. Among BCC, the pathological typing according to the differentiation revealed that 28 cases were solid, 5 cases were adenoid, 2 cases were keratotic and the remaining 5 cases were mixed type (solid-adenoid or keratoticadenoid). Among SCC, 16 cases were classified as welldifferentiated type in 12 cases and moderate-differentiated type in 4 cases. Since 39 of 40 cases of BCC developed on sun-exposed sites, the comparison of pathological findings in relation to the effect of $U V$-exposure was not possible. Of 16 SCC, 9 cases were from sun-exposed sites (face and arm) and 7 cases were from sun-protected sites. No clear difference of pathological findings between SCC on sunexposed sites and SCC on sun-protected was found. Of 40 cases of BCC, 9 cases were $1 \mathrm{~cm}$ or less in diameter (small $B C C$ ) and 31 cases were more than $1 \mathrm{~cm}$ (large $B C C$ ). Large $B C C$ included 13 cases sclerosing infiltrative type. It seems that large sized $B C C$ were frequently associated with 
sclerosing infiltrative type pathologically. The effect of UV on pathological changes in NMSC will be further examined issing a higher number of cases. Of 16 cases of SCC, 7 cases were $1 \mathrm{~cm}$ or less in diameter (small SCC) and 9 cases were more than $1 \mathrm{~cm}$ (large SCC). There was no difference in differentiation of the cells between small SCC and large SCC.

Keywords: skin cancer, basal cell carcinoma, squamous cell carcinoma, histopathological type

In Indonesia, according to a nearly nation-wide data collected from 13 Pathology Laboratories by the National Cancer Registry, the non-melanoma skin cancer (NMSC) ranked the first among males and the fourth among females in 1988 until 1992. ${ }^{1}$ The incidence of NMSC in 1988-1989 was obtained based on a population-based cancer registry in Semarang, Middle Java. It ranked second among males (6.62 per $100,000)$ and third among females (16.54 per $100,000)^{2}$ Histologically, BCC and SCC were the most common types. Many studies, including ours, showed that ultraviolet light (UV) is an important factor in the carcinogenesis of NMSC due to mutagenic effect on cells and imunosuppresive effect on host. ${ }^{3}$

The collaborative study on skin cancer has been conducted to analyze the risk factors and clinicopathological characteristics of skin cancer of both the Indonesian and the Japanese. This study has revealed that the amount of UV exposure was fairly high in Indonesia compared to that in Japan. ${ }^{4}$ Taken together, it is postulated that UV exposure might also be crucial for skin cancer development among the Indonesian. As a matter of fact, the size of NMSC of Indonesian's are often larger compared with those of Japanese.

In this study, we analyzed the histopathological features of NMSC in Indonesian, i.e. 40 cases of BCC and 16 cases of SCC, by focusing on unveiling the relationships of pathological findings, the sites of tumor (sun-exposed vs. sun-protected) and tumor size.

\section{MATERIALS AND METHODS}

During the period of 1996 to 1998 , we observed 40 cases of BCC and 16 cases of SCC. Formalin-fixed, paraffin-embedded tissues were sectioned and stained with hematoxylin-eosin.

Microscopic examination fcr squamous cell carcinoma included the description of the type of cells and grading of malignancy. ${ }^{5}$

Grade I : well differentiated (mild anaplasia, pearl formation and intercellular bridges)
Grade II : moderately differentiated (pearl formation and individual cell keranitization)

Grade III : poorly differentiated (severe anaplasia and a few individual cell keratinization)

Grade IV : undifferentiated (severe anaplasia and no individual cell keratinization)

The diagnosis of basal cell carcinoma was confirmed by describing the differentiation of the cell and growth pattern of the tumor. According to the differentiation of the cells, the tumor was classified into solid type if it was undifferentiated, adenoid type if it was differentiated toward ecrine gland, cystic type if it was differentiated to sebaceous gland, and keratotic type if it was differentiated to hair folicle.

The nature of growth in relation to the possibility of recurrence after the excision was also described, namely nodular, nodular with invasive feature in the peripheral area, infiltrative sclerosing, infiltrative nonsclerosing, and multifocal type. ${ }^{6}$ We have to describe whether the margin of the operation was free from the tumor cells or not.

\section{RESULTS}

Forty cases of BCC were analyzed in this study, 18 were males and 22 were females. The results of the histopathological analyzes are given in Table 1 .

Classification according to differentiation pattern showed that 28 cases $(70 \%)$ were solid type, 2 cases were keratotic type (5\%), 5 cases were adenoid type $(12.5 \%)$ and 5 cases were mixed type (12.5\%).

There was no significant difference of tumor types of $\mathrm{BCC}$ between males and females, and between the young and the old cases.

The growth type of BCC (Table 2) was classified as follows: 8 cases of nodular, 4 cases of nodular infiltrative, 14 cases of sclerosing infiltrative, 11 cases of non-sclerosing infiltrative and 3 cases of multifocal types. No difference was found between males and females and between the young and the old groups. 
The location of $\mathrm{BCC}$ and the type of tumor according to differentiation are shown in Table 3 . Since almost all of the cases developed on sun-exposed sites, characteristics of pathological features related to the UV-exposure was not determined.
When $\mathrm{BCC}$ was divided into small $\mathrm{BCC}$ (diameter less than $1 \mathrm{~cm}$ ) and large $\mathrm{BCC}, 9$ cases were small $\mathrm{BCC}$ and 31 cases were large BCC (Table 4).

Table 1. Distribution of Basal Cell Carcinoma according to histological type in relation to sex and age

\begin{tabular}{|c|c|c|c|c|c|c|c|c|c|c|c|c|c|}
\hline \multirow{3}{*}{$\begin{array}{c}\text { Histological } \\
\text { Type }\end{array}$} & \multicolumn{12}{|c|}{ Age (year) } & \multirow{3}{*}{ Total } \\
\hline & \multicolumn{2}{|c|}{ Sex } & \multicolumn{2}{|c|}{$30-39$} & \multicolumn{2}{|c|}{$40-49$} & \multicolumn{2}{|c|}{$50-59$} & \multicolumn{2}{|c|}{$60-69$} & \multicolumn{2}{|c|}{$70-79$} & \\
\hline & $\mathrm{M}$ & $\mathrm{F}$ & M & $\mathrm{F}$ & M & $\mathrm{F}$ & $\mathrm{M}$ & F & $\mathrm{M}$ & $\mathrm{F}$ & M & $\mathrm{F}$ & \\
\hline Solid & 12 & 16 & 2 & 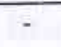 & 4 & 2 & 2 & 6 & 2 & 7 & 2 & 1 & $28(70 \%)$ \\
\hline Cystic & - & - & - & - & - & - & - & - & - & - & - & - & $0(0 \%)$ \\
\hline Keratotic & 2 & - & - & - & 1 & - & - & - & 1 & - & - & - & $2(5 \%)$ \\
\hline Adenoid & 2 & 3 & - & - & - & - & - & 1 & 1 & 1 & 1 & 1 & $5(12.5 \%)$ \\
\hline Mixed & 2 & 3 & - & - & 1 & - & 1 & 1 & - & 1 & - & 1 & $5(12.5 \%)$ \\
\hline Total & 18 & 22 & 2 & 0 & 6 & 2 & 3 & 8 & 4 & 9 & 3 & 3 & 40 \\
\hline$\%$ & (45) & $(55)$ & $(5)$ & $(0)$ & $(15)$ & (5) & $(7.5)$ & $(22.5)$ & (10) & (20) & $(7.5)$ & $(7.5)$ & $(100)$ \\
\hline
\end{tabular}

Table 2. Distribution of Basal Cell Carcinonina according to growth pattern in relation to sex and age

\begin{tabular}{|c|c|c|c|c|c|c|c|c|c|c|c|c|c|}
\hline \multirow{3}{*}{ Growth Pattern } & \multicolumn{12}{|c|}{ Age (year) } & \multirow{3}{*}{ Total } \\
\hline & \multicolumn{2}{|c|}{ Sex } & \multicolumn{2}{|c|}{$30-39$} & \multicolumn{2}{|c|}{$40-49$} & \multicolumn{2}{|c|}{$50-59$} & \multicolumn{2}{|c|}{$60-69$} & \multicolumn{2}{|c|}{$70-79$} & \\
\hline & M & $\mathrm{F}$ & M & $\mathrm{F}$ & M & $\mathrm{F}$ & M & F & M & $\mathrm{F}$ & M & $\mathrm{F}$ & \\
\hline Nodular & 3 & 5 & - & - & 2 & - & 1 & 1 & - & l & - & 3 & $8(20 \%)$ \\
\hline Nodular Infiltrative & 2 & 2 & - & - & - & - & - & 1 & 2 & 1 & - & - & $4(10 \%)$ \\
\hline Sclerosing Infiltrative & 5 & 9 & 2 & - & 1 & 1 & - & 5 & 1 & 3 & 1 & - & $14(35 \%)$ \\
\hline Non-sclerosing Infiltrative & 5 & 6 & - & - & - & 1 & 2 & 1 & 1 & 4 & 2 & - & $11(27.5 \%)$ \\
\hline Multifocal & 3 & - & - & - & 3 & - & - & - & - & - & - & - & $3(7.5 \%)$ \\
\hline $\begin{array}{c}\text { Total } \\
\%\end{array}$ & $\begin{array}{l}18 \\
(45)\end{array}$ & $\begin{array}{c}22 \\
(55)\end{array}$ & $\begin{array}{c}2 \\
(5)\end{array}$ & $\begin{array}{c}0 \\
(0)\end{array}$ & $\begin{array}{c}6 \\
(15)\end{array}$ & $\begin{array}{c}2 \\
(5)\end{array}$ & $\begin{array}{c}3 \\
(7.5) \\
\end{array}$ & $\begin{array}{c}8 \\
(22.5) \\
\end{array}$ & $\begin{array}{c}4 \\
(10) \\
\end{array}$ & $\begin{array}{c}9 \\
(20)\end{array}$ & $\begin{array}{c}3 \\
(7.5) \\
\end{array}$ & $\begin{array}{c}3 \\
(7.5) \\
\end{array}$ & $\begin{array}{c}40 \\
(100) \\
\end{array}$ \\
\hline
\end{tabular}

Table 3. Distribution of Basal Cell Carcinoma according to location and histological type

\begin{tabular}{lcccccc}
\hline Location & \multicolumn{5}{c}{ Histological type } & Total \\
\cline { 2 - 5 } & Solid & Adenoid & Keratotic & Cystic & Mixed & \\
\hline Eyelid & 4 & - & - & - & - & 4 \\
Other part of the face & 23 & 5 & 2 & 0 & 5 & 35 \\
Palm & 1 & - & - & - & - & $\mathbf{1}$ \\
\hline
\end{tabular}

Table 4. Basal Cell Carcinoma growth pattern in relation to its size

\begin{tabular}{lcccc}
\hline \multirow{1}{*}{ Growth Pattern } & \multicolumn{3}{c}{ Size $(\mathbf{c m})$} & Total \\
\cline { 2 - 4 } & $\mathbf{1}$ or less & $\mathbf{1 - 5}$ & more than $\mathbf{5}$ & \\
\hline Nodular & 3 & 4 & 1 & 8 \\
Nodular Inf. & 1 & 3 & - & 4 \\
Sclerosing Inf. & 1 & 12 & 1 & 14 \\
Non-sclerosing Inf. & 3 & 8 & - & 11 \\
Multifocal & 1 & 1 & 1 & 3 \\
\hline \multicolumn{1}{c}{ Total } & $\mathbf{9}$ & $\mathbf{2 8}$ & $\mathbf{3}$ & $\mathbf{4 0}$ \\
\multicolumn{1}{c}{$\%$} & $(\mathbf{2 2 . 5 )}$ & $\mathbf{( 7 0 )}$ & $\mathbf{( 7 . 5 )}$ & $(\mathbf{1 0 0})$ \\
\hline
\end{tabular}


Large BCC consisted of 5 cases of nodular type, 3 cases of nodular infiltrative type, 13 cases of sclerosing infiltrative type, 8 cases of non-sclerosing infiltrative type, and 2 cases of muitifocal type.

In contrast, small BCC consisted of 3 cases of nodular type, 1 case of nodular sclerosing type, 1 case of sclerosing infiltrative type, 3 cases of non-sclerosing infiltrative type, and 1 case of multifocal type.

The relationship between age, sex and the pathological types of SCC are shown in Table 5. Among the 16 cases, 12 cases were well-differentiated type (grade I) and 4 cases were moderate-differentiated type (grade II).

In respect to the sun exposure, 9 cases were from sunexposed sites and 7 cases were from sun-protected sites (Table 6). No pathological differences were found between SCC from sun-exposed sites and those from sun-protected sites.

When the cases of SCC were divided into small SCC (less than $1 \mathrm{~cm}$ in diameter) and large SCC (more than $1 \mathrm{~cm})$, there was no difference in differentiation of the celis between small SCC and large SCC (Table 7).

Table 5. Distribution of Squamous Cell Carcinoma according to histological grading in relation to sex and age

\begin{tabular}{|c|c|c|c|c|c|c|c|c|c|c|c|c|c|c|c|c|c|}
\hline \multirow{3}{*}{ Grade } & \multicolumn{16}{|c|}{ Age (year) } & \multirow{3}{*}{ Total } \\
\hline & \multicolumn{2}{|c|}{ sex } & \multicolumn{2}{|c|}{$20-29$} & \multicolumn{2}{|c|}{$30-39$} & \multicolumn{2}{|c|}{$40-49$} & \multicolumn{2}{|c|}{$50-59$} & \multicolumn{2}{|c|}{$60-69$} & \multicolumn{2}{|c|}{$70-79$} & \multicolumn{2}{|c|}{$80-89$} & \\
\hline & M & $\mathrm{F}$ & $M$ & $F$ & $M$ & $F$ & M & $\mathrm{F}$ & M & F & M & $\mathrm{F}$ & $M$ & $\mathrm{~F}$ & $\mathrm{M}$ & $\mathrm{F}$ & \\
\hline Grade I & 6 & 6 & - & 1 & - & . & - & . & 1 & 1 & 3 & 2 & 2 & 1 & - & 1 & $\begin{array}{c}12 \\
(75 \%)\end{array}$ \\
\hline Grade II & 1 & 3 & - & $\cdot$ & - & 1 & - & - & . & - & 1 & - & - & 1 & - & 1 & $\begin{array}{c}4 \\
(25 \%)\end{array}$ \\
\hline Grade III & 0 & 0 & . & - & . & - & - & . & - & - & - & - & . & - & . & . & - \\
\hline Grade IV & 0 & 0 & - & - & - & - & - & - & . & . & - & - & . & - & - & . & - \\
\hline $\begin{array}{l}\text { Total } \\
\text { (\%) }\end{array}$ & $\begin{array}{c}7 \\
43.75\end{array}$ & $\underset{56.25}{7}$ & $\begin{array}{c}0 \\
(0)\end{array}$ & $\begin{array}{c}1 \\
(6.25)\end{array}$ & $\begin{array}{c}0 \\
(0)\end{array}$ & $\begin{array}{c}1 \\
(6.25)\end{array}$ & $\begin{array}{c}0 \\
(0)\end{array}$ & $\begin{array}{c}0 \\
(0)\end{array}$ & $\begin{array}{c}1 \\
(6.25)\end{array}$ & $\begin{array}{c}1 \\
(6.25)\end{array}$ & $\begin{array}{c}4 \\
(25.0)\end{array}$ & $\begin{array}{c}2 \\
(12.5)\end{array}$ & $\begin{array}{c}2 \\
(12.5)\end{array}$ & $\begin{array}{c}2 \\
(12.5)\end{array}$ & $\begin{array}{c}0 \\
(0)\end{array}$ & $\begin{array}{c}2 \\
(12.5)\end{array}$ & $\begin{array}{c}16 \\
(100)\end{array}$ \\
\hline
\end{tabular}

Table 6. Distribution of Squamous Cell Carcinoma according to location and histological grading

\begin{tabular}{cccccc}
\hline Location & \multicolumn{2}{c}{ Histological grading } & Total \\
\cline { 2 - 5 } & Grade I & Grade II & Grade III & Grade IV & \\
\hline Face & 4 & 3 & 0 & 0 & $\mathbf{7}$ \\
Arm & 2 & 0 & 0 & 0 & $\mathbf{2}$ \\
Foot & 1 & 1 & 0 & 0 & $\mathbf{2}$ \\
Truink & 3 & 0 & 0 & 0 & $\mathbf{3}$ \\
Penis & 1 & 0 & 0 & 0 & $\mathbf{1}$ \\
Leg & 1 & 0 & 0 & 0 & $\mathbf{1}$ \\
\hline
\end{tabular}

Table 7. Distribution of Squamous Cell Carcinoma according to histological grading and size

\begin{tabular}{ccccc}
\hline Grade & \multicolumn{3}{c}{ Size $(\mathbf{c m})$} & Total \\
\cline { 2 - 4 } & $\mathbf{1}$ or less & $\mathbf{> 1 - 5}$ & more than 5 & \\
\hline Grade I & 6 & 3 & 3 & $12(75 \%)$ \\
Grade II & 1 & 2 & 1 & $4(25 \%)$ \\
Grade III & - & - & - & - \\
Grade IV & - & - & - & - \\
\hline Total & $\mathbf{7}$ & $\mathbf{5}$ & $\mathbf{4}$ & $\mathbf{1 6}$ \\
$\%$ & $(\mathbf{4 3 . 7 5 )}$ & $\mathbf{( 3 1 . 2 5 )}$ & $\mathbf{( 2 5 . 0 0 )}$ & $(\mathbf{1 0 0 )}$ \\
\hline
\end{tabular}




\section{DISCUSSION}

Basal cell carcinoma is locally invasive, slowly spreading tumor which rarely metastasize. Histopatologically, the characteristic cell of the basal cell carcinoma, have a large, oval or elongated nucleus and relatively little cytoplasm. For a long time, basal cell carcinoma has been considered to be developed from basal cell of epidermis, but nowadays, it has been suggested that basal cell carcinoma might be developed from a more pluripotent stem cell.

According to the differentiation of cells, BCC is divided into solid type if it is undifferentiated, adenoid type if it is differentiated toward ecrine gland, cystic type, with differentiation to sebaceous gland, and keratotic type if it is differentiated to area of keratinization like the hair follicle. Formerly, this classification was believed to be a good criteria for predicting the prognosis of the tumor, since usually there is correlation between the grade of malignancy and the differentiation of tumor cells, as seen in other malignancies.

Recently, classification of basal cell carcinoma according to the growth pattern has been considered to be more correlated to the aggressiveness of the tumor and is potential to recurrence.

Squamous cell carcinoma may show considerable variation. The cells usually show grade variation in size. Variants of squamous cell carcinoma are adenoid squamous cell carcinoma and spindle cell type squamous cell carcinoma.

Brodérs has divided squamous cell carcinoma using the percentage of the undifferentiated cells into grade I, II, III and IV. However, it is not easy to count the cells, so in later publication the criteria was modified.

Sun-exposure is a crucial carcinogen of NMSC. CC to TT mutations and $\mathrm{C}$ to $\mathrm{T}$ mutations at dipyrimidine sites are frequently observed in $\mathrm{p} 53$ tumor suppressor gene of NMSC developed on sun-exposed sites.

In the current study, we attempted to analyze the pathological characteristics of BCC and SCC, in relation to the effect of sun-exposure. In previous report, adenoid type (pseudoglandular, acantholytic type) of SCC has been suggested to be associated with sun-exposure. ${ }^{5}$ However, we did not find this type of SCC in this study.
Our data showed that sclerosing infiltrative type of $\mathrm{BCC}$ was frequently found in large BCC. This is consistent with the previous study that showed that the sclerosing infiltrative type of $\mathrm{BCC}$ was more aggressive as measured by the high number of AgNOR and PCNA positivity. 8,9

Larger number of the cases of NMSC will be necessary for evaluating the histopathological characteristics associated with UV exposure. In addition to morphoiogical analysis on HE stained section, study on $\mathrm{p} 53$ or Ki67 by immunohistochemistry may help to distinguish the difference in relation to uv-induced molecular changes.

\section{Acknowledgement}

We are grateful to the International Cancer Research Grant system, Monbusho, Japan and the Dean, Faculty of Medicine, University of Indonesia, Jakarta for the approval of the Japan-Indonesia collaborative study. The collaborative study was initiated with Dean's approval no. 845/PT02.H4.FK/E/97. Also, to the Director of Dr. Cipto Mangunkusumo National ' Central General Hospital, we would like to thank his technical assistance. This work has been supported by the grant no. 09042004, under Ministry of Education, Science, Sport and Culture, Government of Japan and was partly supported by the Indonesian Cancer Foundation, the Jakarta International Cancer Conference Fund and the Terry Fox Foundation, Canada.

\section{REFERENCES}

1. Comain S, Mangunkusumo R, Nasar IM, Prihartono J. Ten most frequent cancer in Indonesia. Pathology Based Cancer Registry Data of 1988-1992. In: Cancer Registry in Indonesia, National Cancer Registry Center, Jakarta 1997.

2. Sarjadi. Cancer Incidence 1985-1989 in Semarang Indonesia. Indonesian Cancer Society 1990.

3. Ueda M, Kanoko M, Cornain S, Hamzah M, Poetiray E, Ichihashi M, Prihartono J, Ohno $\mathrm{Y}$. Molecular pathological changes induced by ultraviolet light during the develgpment of skin cancer. Med. J. Indonesia, 2000; 9:118-22.

4. Munakata N, Comain S, Mulyadi K, Ichihashi M, Prihartono J, Ohno Y, Hamzah M, Kanoko M, Poetiray E, Budiningsih S, Tjarta A, Ueda $M$, Tjipto $H$, and Mukhtar A. Biologically effective doses of ambient solarUV radiation in Indonesia and Japan. Med. J. Indonesia, 200; 9:123-8. 
5. Lever WF, Lever GS. Histopathology of the skin. 7th ed. JB Lippincott Comp. Philladelphia. 1990.

6. Sloane JP. The value typing basal cell carcinoma in predicting recurrence after surgical excision. BR J Dermatol. 1977, 96:127-32.

7. Nakazawa H, English D, Randell PL, Nakazawa K, Martel $\mathrm{N}$, Armstrong BK, et al. UV and skin cancer specific p53 gene mutation in normal skin as a biologically relevant exposiare measurement. Proc Natl Acad Sci 1994; 91: 360-4.

8. Jeksono P. Nilai AgNOR sebagai petunjuk untuk menentukan residif pada basalioma. Thesis in partial fulfillment of the specialty examination in pathology. 1995.
9. Kanoko M. Index of Prolifierating Cell Nuclear Antigen (PCNA) in Basalioma; correlation with the histopathological type. Presented in the $4^{\text {th }}$ Congress AsiaPacific Association of Societies of Pathologists. Beijing, China. 1995.

10. Ro YS, Kim JH. Immunohistochemical analysis of p53 protein expression in benign and malignant skin tumors using a panel of anti-p53 antibodies. J Korean Med Sci 1993; 8: 361-6.

11. Ro YS. Oncogene interaction in basal cell carcinomas of human skin. J Korean Med Sci 1995; 10: 85-92 